\title{
Analysis on the Quality of Educational Services in an Effort to Improve the Image of Higher Education
}

\author{
Puspo Dewi Dirgantari \\ Program Studi Pendidikan Bisnis, Fakultas Pendidikan Ekonomi dan Bisnis, Universitas \\ Pendidikan Indonesia, Bandung, Indonesia
}

\begin{abstract}
Education is one of the most effective tool in changing people. Along with the globalization that continues to occur at high speeds that touch every aspect of human life is also touched education globally. These changes make the college market and competition becomes more widespread than previously and the relative moving faster than the ability of universities to respond. Currently, there are ranking universities in the world of international standards by agencies recognized by the world. in 2011, not a single university in Indonesia recorded the world's top 50 universities in both versions Webometrics and the QS World University Rankings. This shows that the competitiveness of universities in Indonesia are still not strong enough in comparison with universities abroad that ultimately the competitiveness of these colleges will build the image of college. The image has a very important meaning for the institution. The method used in this study is descriptive and explanatory survey of a sample survey with a size of 100 foreign students. The research was conducted within a period of less than one year (not sustainable in the long run) so that the method used is a cross-sectional. The data used are the primary data and secondary data collected through the literature study and questionnaire. The results revealed that the quality of education services at public universities in Bandung classified into good category, this means that the service received or perceived by foreign students has been as expected and the quality of education services affect the image of public universities in Bandung.
\end{abstract}

Keywords : Quality of Education Services; Image; Higher Education

Corresponding author. E-mail address: puspodewi@upi.edu

Received December 2018; Received in revised February 2019; Accepted May 2019

International Journal Management \& Busines Vol 1, No 1 (2019) 27-40

\section{Introduction}

Education is one of the most effective tool to change people, impact the quality of education in the formation of human beings have a power of two or three times more powerful than others. The task of education is to improve the quality of the individual to be more productive, education served as a function of social control, preservation of culture, training centers and workforce development and the formation of attitudes
(Inkeles \&Smith, 1974:304 in EA Kuncoro, 2008:90).

The success of a nation in the education building is also a barometer of the nation's rate of progress (Soemarto, 2002:10). WEF (World Education Forum) in 2010 reported that the positive impact of educational advancement, among others, can best be seen from the demographic structure, increasing the quality of life and the achievement of development in various sectors (Nandika, in EA Kuncoro 2006:2, 
2008:90). Therefore, given the central role of education for the progress of the construction of a nation, it is not surprising that many countries give priority to the development of education sector

Higher education is one important pillar, which is expected to bring changes to the nation, because higher education is to train people to sharpen and use his reason to solve the problems it faces. According to Drost (1990:124), higher education serves as a reason to humanize the human environment in accordance with the image of man.

According to the Law on National Education System No. 20 of 2003 (Article 20 paragraph 1), which organized the educational unit of higher education, called by the name of the college, can forms the status of the Academy, Polytechnic, College, Institute or University, with the following specifications:

1. Academy, vocational education in a one branch or part of the branch of science, technology, and/or a specific art

2. Polytechnic, vocational education in a field of specialized knowledge

3. College, academic education and/or vocation within the scope of a particular discipline, and if eligible to provide education profession

4. Institutions, college education and/or vocational education in a group of disciplines of science, technology, and/or the arts, and if eligible to provide education profession

5. Universities, academic education programs and/or vocational education in a number of science, technology, and/or art and if eligible to provide education profession.

Along with the globalization that continues to occur at high speeds that touch every aspect of human life globally, it is touching the world of education as well. Global education is the world's infrastructure community development. Globalization of education is eliminating the boundaries that had hindered the development of global education. Globalization through the wall of the geographical, cultural nationalism and even civilization of nations, so that the globalization of education as a charge, can not be prevented anymore by any country and the world community.

These changes make the college market and competition becomes more widespread than previously and the relative moving faster than the ability of universities to respond. There is now ranking universities in the world of international standard by institution swhich are recognized by the world, such as:

1. Times Higher Education Supplement (THES) from England. THES assessed based on four factors, namely the quality of research, the absorption of graduates into the workforce, international achievements, as well as the quality of teaching.

2. QS World University Ranking of America (U.S. News). QS WUR academic criteria based on the quality of research (academic per review), the ratio of students to teaching staff (student to faculty ratio), the results of a study cited (citations per paper), ie how many university-related research cited, the readiness of graduates enter the world of work (employer review) is a survey to obtain information about the job readiness of graduates and the level of satisfaction, the number of foreign students (international students) is the number of international students, international faculty and the number of lecturers who come from abroad to teach at a university. 
3. Webometrics Ranking of World Universities, based in Spain. The institute is better assess aspects of access to scientific publications to enhance the academic presence on web sites. Based on a combined indicator that takes into account the volume or web content, visibility, and impact of web publications.

4. Academic Ranking of World Universities (ARWU), Shanghai Jiao Tong University was initiated, the ranking weight to formulate more stringent, such as the alumni are Nobel Prize winners and international awards, the
Nobel Prize winning faculty, and conduct a study cited in 21 broad subject categories. (Source: Koran Tempo, 17 April 2010, Towards a World Class University, accessed on07.08.2011, at 13:03)

The following is the best in the world rankings in 2010 based on its presence in the internet. Based on excellence in electronic publishing (e-publication) is contained in the web domain of each college. College, best universities world today, also has a very good Webometrics ranking.

Table 1. Ranking of the Best Universities in the World Version of Webometrics

\begin{tabular}{|c|c|c|c|c|c|c|c|c|}
\hline \multicolumn{3}{|c|}{ World Rank } & \multirow{2}{*}{ University } & \multirow{2}{*}{ Country } & \multicolumn{4}{|c|}{ Position } \\
\hline 2009 & 2010 & 2011 & & & Size & Visibility & Richfiles & Scholar \\
\hline 1 & 2 & 1 & $\begin{array}{l}\text { Massachusetts Institute of } \\
\text { Technology }\end{array}$ & America & 2 & 1 & 3 & 10 \\
\hline 3 & 1 & 2 & Harvard University & America & 7 & 4 & 16 & 1 \\
\hline 2 & 3 & 3 & Stanford University & America & 4 & 3 & 1 & 48 \\
\hline
\end{tabular}

(Sumber: http://www.webometrics.info/top12000.asp, diakses tanggal 15/04/2011, jam 13:59)

Table 2. World Ranking of Indonesian Universities Version of Webometrics

\begin{tabular}{|c|c|c|c|c|c|c|c|}
\hline \multicolumn{3}{|c|}{ World Rank } & \multirow{2}{*}{ University } & \multicolumn{4}{|c|}{ Position } \\
\hline 2009 & 2010 & 2011 & & Size & Visibility & Richfiles & Scholar \\
\hline 562 & 611 & 583 & universitas gadjah mada & 501 & 815 & 1,152 & 71 \\
\hline 815 & 789 & 599 & university of indonesia & 438 & 969 & 634 & 11 \\
\hline 661 & 569 & 770 & institute of technology bandung & 444 & 908 & 919 & 529 \\
\hline$\cdot$ & & & . & . & & & \\
\hline$\cdot$ & & & $\cdot$ & $\cdot$ & & & \\
\hline 2298 & 2182 & 1880 & indonesia university of education* & 1,516 & 1,081 & 2,356 & 3,111 \\
\hline 2236 & 1834 & 1927 & universitas padjadjaran & 1,411 & 3,037 & 2,522 & 2,066 \\
\hline
\end{tabular}

Webometrics measurements using four indicators, namely size, visibility, rich files, and scholar. The first indicator, size (S), the number of pages contained in this electronic publication college web domain. Second, the visibility $(\mathrm{V})$ is another page that lists the number of URLS (Uniform Resource Locator is a sequence of characters according to a certain standard format, which is used to indicate the address of a resource such as documents and images on the Internet) are assessed higher education domain. Third, rich files (RF), the relevance of electronic sources in academic activities and university publications. Finally, scholar (Sc), the number of publications and quality situation in the university domain.

Meanwhile, according to QS World University Rankings versions that provide information/guidance on what the objective might be considered for college students. QS, 
International Journal Management Science \& Business

Vol 1, No 1, 2019, pp 27-40

do what it takes to push the evaluation to a more contextually-focused on the area, subjects and an interactive online system where enquirers will be able to choose their own criteria and apply their own weighting, the goal is to evaluate the university's more than angle is more for more people

Table 3. The Qs World University Rankings-Top Universities

\begin{tabular}{cccccccc}
\hline Rank & Rank & School Name & Country & Size & Research & Focus & Score \\
$\mathbf{2 0 0 9}$ & $\mathbf{2 0 1 0}$ & & & & $\mathbf{2 0 1 0}$ \\
\hline 2 & 1 & University of Cambridge & United Kingdom & L & VH & FC & 100.00 \\
1 & 2 & Harvard University & United States & L & VH & FC & 99.18 \\
3 & 3 & Yale University & United States & M & VH & FC & 98.68 \\
\hline
\end{tabular}

(Sumber: QS Quacquarelli Symonds, www.topuniversities.com, diakses tanggal 15/04/2011, jam 13:59)

Table 4. World Ranking of Universities in Indonesia Version of The Qs World University Rankings

\begin{tabular}{|c|c|c|c|c|c|c|}
\hline $\begin{array}{l}2005 \\
\text { Rank } \\
\end{array}$ & $\begin{array}{l}2006 \\
\text { Rank }\end{array}$ & $\begin{array}{l}2007 \\
\text { Rank }\end{array}$ & $\begin{array}{l}2008 \\
\text { Rank }\end{array}$ & $\begin{array}{l}2009 \\
\text { Rank }\end{array}$ & $\begin{array}{l}2010 \\
\text { Rank }\end{array}$ & School Name \\
\hline $526=$ & $526=$ & $502=$ & $501+$ & $401-500$ & $451-500$ & Airlangga University \\
\hline $258=$ & $258=$ & $369=$ & 315 & $351=$ & $401-450$ & Bandung Institute of Technology (ITB) \\
\hline $0=$ & $0=$ & $545=$ & $501+$ & $501-600$ & $501-550$ & Bogor Agricultural University \\
\hline \multirow[t]{2}{*}{$495=$} & $495=$ & 553 & $501+$ & $501-600$ & $\begin{array}{c}601+ \\
\mathrm{N} / \mathrm{A}\end{array}$ & $\begin{array}{l}\text { Diponegoro University } \\
\text { Padjadjaran University }\end{array}$ \\
\hline & & & & $601+$ & $601+$ & Sepuluh Nopember Institute of Technology \\
\hline \multirow[t]{2}{*}{$270=$} & $270=$ & $360=$ & $316=$ & 250 & $\begin{array}{l}321 \\
N / A\end{array}$ & $\begin{array}{l}\text { Universitas Gadjah Mada } \\
\text { Universitas Pendidikan Indonesia }\end{array}$ \\
\hline & & $\mathrm{N} / \mathrm{A}$ & $501+$ & $501-600$ & $601+$ & University of Brawijaya \\
\hline $250=$ & $250=$ & 395 & 287 & $201=$ & 236 & University of Indonesia \\
\hline
\end{tabular}

(Sumber: QS World University Rankings ${ }^{T M}$ Copyright (C) 2011 QS Intelligence

Unit,http://www.topuniversities.com/search/universities/indonesia?filters=ss_profile_country\%3Alndonesia\&solrsort=sort _title\%20asc diakses tanggal 12/05/11, jam 10:55))

Based on Table 4 no visible universities in Indonesia are included into the world's top 50 universities in both versions Webometrics and the QS World University Rankings This shows that the weak competitiveness of universities in Indonesia compared to universities abroad that ultimately the competitiveness of this college will build the image of college.

The university's image can be defined as the sum of all the beliefs of the individual against the university (Landrum et al (1998) and Arpan et al (2003) in Helena Alves and Ma'rio Raposo, 2010:73-85). The image is a number of beliefs, ideas and impressions held by a person against an object (Kotler, 2009:406)
To be a part of globalization and/or the world community colleges in Indonesia should try to become a world-class universities.

One of the world-class university assessment criteria is the presence of foreign students (international student) who attend the university, due to international or world-class image is a must-have component of the current world-class university. One way to evaluate it is to assess the proportion of international students and faculty are most interested in the institution.

Presence of foreign students is one step to make higher education in Indonesia is the world class level. Foreign students is a sign that our college has been recognized by the 
international. In developed countries, attract foreign students is not simply just to improve the image of college is like in America, education has become a very lucrative business fields. this superpowers country, every year succeeded in obtaining foreign exchange up to U.S. \$ 13 billion, just from "selling" the campus. So also in Singapore, the number of students and foreign students studying in the country, currently account for about 80 thousand people, one might say, is an indicator of economic progress. There are estimates, only from the education sector alone, each year the Government of Singapore has earned about four trillion dollars. So it is not surprising that Singapore is so actively promoted to foreign countries through the agency of Singapore Education Service Center (SESC). (Source: http://www.majalahtrust.com/bisnis/strategi/ 1532.phpm, accessed 01/01/2011, at 15:04)

Thus, the image of the company has great significance for the company. According to Ham and Hayduk (2003) in Buchari Alma (2008:98), in order to achieve competitiveness of higher education there are three factors that affect global issues and to all organizations, whether large or small, profit organization and nonprofit organizations, as well as local companies and global levels, including college. The third factor is service quality, customer satisfaction and behavioral intentions. The same is expressed by other researchers who claimed that the market has high competition, satisfaction with the services will have differences. Possible satisfaction can affect what is perceived student to accept or reject.

Therefore, to establish a good image of the institution, in order to attract a number of local and international students, the college, not just pay attention to the satisfaction of students also must continue to improve the quality of its services.

According to Bowen \& booms (1983) in Fandy Tjiptono (2008:85), service quality is a measure of how good the level of service provided in accordance with customers expectation. If the services received or perceived as expected, then its considered good perceived service quality and satisfying. If the services received lower than expected, then the perceived quality of services considered as poor. Conversely if the services received exceed the expectations of consumers, the quality of service perceived as an ideal quality. Thus whether or not the quality of service depends on the ability of providers to meet consumer expectations consistently.

Among universities of the world, ranking it (the results of the 3000 education experts from around the world) is considered quite prestigious. Moreover, this ranking can be used as benchmarks to assess the quality of college education. The ranking can be used as media for the college is meant to attract more foreign students. The chances are that way is still open. It was revealed from the survey results Internationale Institute of Education (research institute of America) in 2009. 2.5 million respondents, from across the globe among the students surveyed, not least among them (no exception students from developed countries) that began to interest in studying at several universities of developing countries. Among them, about $6 \%$ interest to go to college in China. That beat enthusiasts who want to study in Japan (only 5\%) and Canada (3\%). Meanwhile, most of them (22\%), it still chose America as the ultimate goal for a degree. (Source: http://www.majalahtrust.com/bisnis/strategi/ 1532.php, accessed 01/01/2011, at 15:04) 
International Journal Management Science \& Business

Vol 1, No 1, 2019, pp 27-40

Bandung became one of the foreign students to attend school due to various reasons such as weather, food, friends, family, to guarantee the quality of university education in Bandung and the cost of education low. Head of immigration Bandung, Rahmat Tanjung said foreign students in Bandung have increased about $10 \%$ every year. They come from Timor Leste, Korea, Malaysia, and Europe. Foreign students from Europe and America chose Indonesia to study the cultural riches. In 2007, has registered about 1000 foreign students study in Bandung. While students who had graduated as many as 200 people. The presence of foreign students provide distinct advantages for society and government such as income, cultural exchange, knowledge and so forth. (Source: newspaper Media Indonesia, 11 Sep 2007)

Bandung Institute of Technology, University of Padjajaran and Education University of Indonesia, located in Bandung City is a public university owned by Indonesia which has been selected to be one option to continue their foreign students to pursue higher degrees. Based on this background, we need to hold research on: "The Influence of Educational Services Quality Improvement Efforts Against the image of the State University in Bandung Towards a World Class University"

\section{Literature Review}

Marketing is the process of planning and executing the conception, pricing, promotion, and distribution of ideas, goods and services to create exchange that satisfy individual and organizational objectives (Kotler, 2009:407)

Services (service) is any act or performance that may be offered one party to another that is essentially intangible and does not produce any kind of ownership (Kotler,2009:410)

Marketing of education services is an activity or institution providing services deliver educational services to consumers in ways that satisfy (Buchari Alma and Ratih Hurriyati, 2008:30).

\section{Quality Of Service}

Goeth and Davis in Fandy Tjiptono (2005:110) defines quality as dynamic conditions relating to products, services, human resources, processes and environments that meet or exceed expectations.

Simply the quality of service can be interpreted as a measure of how good the level of service provided in accordance with customer expectations can (Lewis \& booms, 1983, in Fandi Tjiptono, 2008:85). From this definition, service quality can be realized through the fulfillment of customer needs and wants as well as timeliness of delivery to match customer expectations. In other words, the main factors affecting the quality of service is a service that is expected (expected service) and perceptions of service (perceived service) (Parasuraman, et al, 1985). If the service is received or perceived as expected, then good perceived service quality and satisfaction. If the services received exceed customer expectations, perceived quality of the service quality of an ideal. Conversely, if the services they received lower than expected, then the perceived service quality is poor.

In this study the quality of the services used by the six dimensions of quality of educational services Mohammad S Owlia and Elaine M Aspinwall (1996:12-20), which has been adjusted: (1) Tangibles, with indicators of residence halls, facilities teaching and learning activities (space lectures, labs, etc.), library 
facilities, IT Infrastructure, Facilities religious support for international students, medical facilities, activities/student organizations, sports facilities, student accommodation (2) Competence, the indicator ratio in the number of lecturers with foreign students, the ratio of qualifying lecturer S2, S3, Professor or Professor, the ability of lecturers in full mastery of teaching materials and teaching methods of both pedagogical and methodical (professional competence lecturer), The relevance of knowledge and/or instructional materials with a phenomenon that is happening (up to date), Capability teaching (pedagogical competence professor), professor of psychological potentials for educational tasks, such as need for achievement, work, change, and autonomic (personal competence), and so (3) Attitude, with indicators of Modesty and neatness lecturer, Respect and a fair value of foreign students, a great sense of responsibility for the future of students, Be patient to face students without the use of emotion in the act, currently teaching faculty of speech and/or speak clearly, creating a good classroom, teachers' willingness to provide guidance and advice on foreign students, lecturers' willingness to help, hang out and serve the students relating to faculty employment, etc. (4) Content, with indicators of curriculum relevance to the needs and desires of students, service to-face learning, service learning structured tasks and/or independent, Service learning outside the classroom, Consolidation, try out, program officials, and so on, availability of foreign students coming service (pick up service) and return, availability of foreign students making documents such as passports, visas, health insurance, bank accounts, and police report Service, academic administration, student affairs and finance (5) Delivery, Timeliness indicators lecture delivery of content, consistency of delivery of lecture content, accuracy and fairness evaluating learning outcomes, timeliness of delivery of administrative services, consistency of delivery of administrative services, precision / accuracy in every service given (6) Reliability, with the indicator, Ability to maintain trust, keeping promises accuracy to fit the purpose, ability to handle complaints and solving problems.

\section{Image}

According to Sutisna (2001:83) is the total image of the perception of an object formed by processing information from various sources all the time. Meanwhile, according to Kotler (2009:406), the image is a set of beliefs, ideas and impressions held by a person against an object, the attitude and actions towards people is largely determined by the image of the object. Image of the institution is described as an overall impression on the minds of the public about an organization (Barich and Kotler, 1991 in Nha Nguyen and Gaston LeBlanc. 2001)

According to Landrum et al (1998) and Arpan et al (2003) image of the university can be defined as the sum of all the beliefs of the individual against the university. Mazursky and Jacoby (1986) is the image of cognition and/or effect is inferred, either from a set of ongoing perception and/or memory attached to the input that represents the phenomenon and the phenomenon of what is marked on the individual. In addition, some images and image attributes can be implemented and even different. The image can be interpreted positively, neutral or negative toward the organization (Kazoleas et al, 2001) (in Helena Alves and Ma'rio Raposo, 2010)

Dimensional image of the company relating to the overall picture of an organization is perceived by customers. It is the result of a 
combination of technical and functional quality dimensions as well as factors such as prices of products (or services) and corporate reputation (Mohammad S Owlia and Elaine M Aspinwall, 1996:12-20)

In this study, the college's imageforming component that is used from Asuncion Beerli Palacio, Gonzalo and Pedro J. Diaz Meneses Perez (2002:486-505), namely (1) The cognitive component, with the indicator paper/research paper published in many international lecturer. Lecturers who come from abroad who teach in universities, teaching and learning process is very good at, the University has a well known internationally, has a ranking or rating of excellence in specific areas, the University has support services are good career guidance, the University has the resources good for students (such as computer equipment, library, transportation, etc.), etc. (2) an affective component, with a desire to follow the program indicators-such as the double degree program, Fulbright, sandwiches, etc. at universities, assessment of this university at the international level, your appreciation of this university, your ability to interact with social and cultural environment at the university.

\section{Hypotheses}

Ho: $\rho \leq 0$, meaning there is no influence of the quality of educational services on improving the image of public universities in Bandung toward world class university.

Ha: $\rho>0$, meaning that there is influence between the quality of educational services on improving the image of public universities in Bandung toward world class university.

\section{Subjects Research}

This study uses the marketing management approach, especially regarding the influence of the quality of educational services on improving the image of public universities in Bandung toward world class university. The independent variables (independent variables) in this study is the quality of education services. Quality of education services created by Tangible, Competence, Attitude, Content, Delivery, Reliability. For the dependent variable (dependent variable) is the image of the college formed through cognitive and affective components.

The research was carried out on foreign students at public universities in Bandung, the population is used as the unit of observation is a whole school of foreign students at Bandung Institute of Technology, Padjadjaran University, and Indonesia University of Education.

\section{Research Methods}

Based on the research objectives, this research is descriptive research and verifikatif. Descriptive research is research conducted to determine the value of independent variable, either a variable or more without making comparisons, or connect with other variables (Sugiyono, 2003:11). This descriptive study aims to obtain a description of the variable elements of service quality and image. Verifikatif wanted to test the truth of a hypothesis which is done through data collection in the field (Suharsimi Arikunto, 2002:7). In this study will be tested whether the quality of education services have an influence on the image of public universities in Bandung with the research method used is an explanatory survey is intended to explain the causal relationships between variables through the testing of hypotheses.

The study was conducted within a period of less than one year so that the method used is 
the cross-sectional study method by studying objects in a certain period of time (not sustainable in the long run). (Umar Husain, 2003:45)

\section{Population}

Sugiyono (2005:90) explains that: "The population is composed of the generalization of the object or subject that has certain qualities and characteristics are determined by there searchers to learn and then drawn conclusions". Based on the above understanding is that a target population in this study were foreign students at public universities, namely Bandung Institute of Technology, Padjadjaran University, and Indonesia University of Education as many as 1204 students.

\section{Samples}

Samples according to Sugiyono (2007:73) is: "Part of the amount and characteristic spossessed by the population". In determining the sample size in this study used a sample formula Slovin (Hussein Omar, 2003: 141). Slovin formula samples with minimal sample size used in this study with $\alpha=0.1$ and $10 \%$ confidence level, the obtained sample size $(n)$ of at least 92 people. According to Winarno Surakhmad (1998:100) that "In order to guarantee the sample is always a good idea plus a little more than the number of mathematics". To be more representative samples used in this study, the samples used were 100 respondents to the calculation of the sample proportional to Bandung Institute of Technology, as many as 14 people, as many as 82 people Padjadjaran University, and University of Education Indonesia by 4 people.

\section{Sampling Techniques}

According Arikunto (2006:133) sampling must be done in such a way as to obtain a sample that can truly serve as an example or to illustrate the state of the actual population. Sampling technique used in this study is simple random sampling is the sampling of each population was randomly without regard to the strata that exist in this population.

\section{Data Analysis Techniques}

Data analysis techniques used in this study were of regression analysis. When there searchers used regression analysis intends to find out how the dependent variable /criteria can be predicted by the independent or predictor variables, individually. The impact of the use of regression analysis can be used to decide whether the rise and decline in the dependent variable can be done through raising and lowering the state of independent variables, or to improve the state of the dependent variable can be done by increasing the independent variable/and vice versa (Sugiyono, 2004: 204).

equation is:

General simple linear regression

$$
\begin{aligned}
Y & =a+b X \\
a & =\frac{\left(\sum Y_{i}\right)\left(\sum X_{i}^{2}\right)-\left(\sum X_{i}\right)\left(\sum X_{i} Y_{i}\right)}{n \sum X_{i}^{2}-\left(\sum X_{i}\right)^{2}} \\
b & =\frac{n \sum X_{i} Y_{i}-\left(\sum X_{i}\right)\left(\sum Y_{i}\right)}{n \sum X_{i}^{2}-\left(\sum X_{i}\right)^{2}}
\end{aligned}
$$

Description:

$Y=$ Subject/value in the dependent variable is predicted, $a=$ value of $Y$ when $X=0$ (constant prices), $b=$ number of direction or regression coefficient, which indicates an increase or decrease the number of variables independent 
International Journal Management Science \& Business

Vol 1, No 1, 2019, pp 27-40

based on the independent variable. If $b(+)$ then go up, and when (-) then there is a decrease, $X$ $=$ Subject to the independent variables that have a particular value.

\section{Results and Discussion}

\section{Foreign Student Response Against State} Universities Quality of Service in Bandung

Goeth and Davis (in Fandy Tjiptono, 2005:110) defines quality as dynamic conditions relating to products, services, human resources, processes and environments that meet or exceed expectations. According to Kotler (2007:180), the overall quality characteristics and the nature of goods and services that affect the ability to meet the needs expressed or implied.

Picture quality of education services at public universities in Bandung is done through an explanation of six dimensions, namely tangibles, competence, attitude, content, content, delivery, and reliability.

Based on the scores of foreign students obtaining feedback on the quality of education services at public universities in Bandung is19258 compared to the ideal score is 25000 for 50 items question the quality of education services at public universities in Bandung include both categories, meaning that the service received or perceived by foreign students as expected. This is in accordance with the opinion Parasuraman, et al (1985) that If the services received or perceived as expected, then good perceived service quality and satisfaction. If the services received exceed customer expectations, perceived quality of the service quality of an ideal. Conversely, if the services they received lower than expected, then the quality of service perceived to be bad.

\section{Preview Image of State Universities In Bandung}

According to Philip Kotler (2009:406), the image is a set of beliefs, ideas and impressions held by a person against an object, the attitude and actions towards people is largely determined by the image of the object. Meanwhile, according to Sutisna (2001:83) is the total image of the perception of an object formed by processing information from various sources all the time.

\section{Preview image of public universities in Bandung done through cognitive and affective components}

Based on the scores of foreign students obtaining feedback on the image of public universities in Bandung is an ideal score is 6260 compared to 8000 then the image of public universities in Bandung including the positive category, meaning that foreign students have a level/degree of a set of beliefs, ideas and impressions are positive and high or means, the public universities in Bandung is known as an international student.

This is in accordance with the opinion Sutisna (2001:334) that "one thing that analyzed why it appears there is an organization of the company's image problem known or unknown". It is understandable that companies do not fame both show the troubled company's image. The company's image problem in existence in the mind and/or feelings. According to Robinson and Barlow's "corporate image may come from direct experience" Its existence stems from the experience of the university image and/or communication efforts so that the assessment of development nor occur in either or both. University image that comes from experience give you an idea has occurred engagement between consumers and 
International Journal Management Science \& Business

Vol 1, No 1, 2019, pp 27-40

university. Engagement, unprecedented

Tests of Hypotheses

incorporate image sourced from the university

communications efforts.

Tablr 5. Tes of Hypotheses

\begin{tabular}{|c|c|c|c|c|c|c|}
\hline \multicolumn{7}{|c|}{ Coefficients $^{\mathrm{a}}$} \\
\hline & \multirow[t]{2}{*}{ Model } & \multicolumn{2}{|c|}{ Unstandardized Coefficients } & \multirow{2}{*}{$\frac{\text { Standardized Coefficients }}{\text { Beta }}$} & \multirow[t]{2}{*}{$\mathbf{t}$} & \multirow[t]{2}{*}{ Sig. } \\
\hline & & B & Std. Error & & & \\
\hline \multirow[t]{2}{*}{1} & (Constant) & 1.151 & .294 & & 3.913 & .000 \\
\hline & Kualitas & .699 & .071 & .704 & 9.817 & .000 \\
\hline
\end{tabular}

Based on the above table, the regression equation can be obtained as follows:

$Y=1.151+0.699 X$

Where $Y$ is the image of $X$ is the Higher Education and Quality of Service. Regression coefficient of 0.699 states that every $1 \%$ increase in the quality of the image will be an increase in higher education by $69.9 \%$

By comparing the calculated statistics with the statistics table is $9.817>1.984$ with a significance level $(\alpha)<0.05$, df (degrees of freedom) $=\mathrm{n}-2=100-2=98$ and two-sided test done then $\mathrm{HO}$ is rejected, or affect the quality of service significant on improving the image of public universities in Bandung.

Foreign student services available at ITB, UNPAD, and UPI as follow:

ITB are constantly improving the educational curriculum. ITB has worked with dozens of universities, both in Asia and Europe. This strategy is also a form of promotion that ITB is better known in various countries. (Source: http://www.majalahtrust.com/bisnis/strategi/ 1532.php, accessed 01/01/2011, at 14:44). ITB through the International Relations Office (IRO), help international students and scholars, to prepare for their visit to the ITB, including visa arrangements and other information to make a stay in Bandung comfortable and enjoyable, such as the Accommodation Arrangement,
Police Report, opening bank accounts, insurance health and so on. IRO ITB also provide information for ITB students, faculty and staff about student exchange programs and staff, as well as scholarships offered by foreign universities and other funding agencies. (Source: http:// www.international.itb.ac.id/web/?p=3178, accessed on 06.01.2011, at 11:15).

UNPAD through PADMA support and implement international education, which meet the standards of world-class universities, organize promotional activities and marketing activities to recruit students from target countries (educational exhibits, presentations, seminars, information, advertising, visits to schools in target countries as well as in Indonesia and others). PADMA in cooperation with the Embassy of the Republic of Indonesia in Malaysia, organized the exhibition to promote education for Indonesian education institutions that already has an international program. Consultations on education and nonacademic programs that are being promoted. Registration and admission of students, both conventional and online systems. Help students with many facilities and support services - from 
International Journal Management Science \& Business

Vol 1, No 1, 2019, pp 27-40

the arrival of the students (pick up service), serving students with a complete and comfortable accommodation for foreign students-PADMA provide student residences (Padjadjaran Bale) who has been equipped with facilities such as: mini mart, an Internet connection, lounge, canteen, sports and fitness facilities, and entertainment facilities. Assist in student immigration documents, health care services by Clinic Padjadjaran. Travel and tourism services by Padma Tour and Travel as well as Internet and IT services. (Source: http://www.padma-edu.com/, accessed on 06/01/2011, 11:00)

UPI through its Office of International Education and Relations (OIER) assist in the admission of international students, providing advisory and support program for international students, student dormitories, scholarships, student activity center and so on. (Source: http://upi.edu/en/index.php? C = Inter \& S = Office, accessed on06.01.2011, at 11:07).

\section{Conclusion}

The response of foreign students on the quality of educational services, public universities in Bandung is rated good, meaning that the service received or perceived by foreign students in accordance with the expected

Level image of public universities in Bandung is rated positively, meaning that foreign students have a level/degree of a set of beliefs, ideas and high or positive impression, also means public universities in Bandung is known by international student.

Influence from the quality of educational services on improving the image of public universities in Bandung is considered positive

\section{Recommendation}

Efforts to improve the image of college can be done while maintaining the target level of recognition for products and services of the university through increased public relations campaign. Meanwhile, to maintain a positive image can be done affectively continue through the communication/development.

Deficiencies or weaknesses of this study one of them is the number of samples based on proportional math calculations for UPI only 4 people that are less represented. Therefore, the next sample can be re-examined.

\section{References}

Asuncion Beerli Palacio, Gonzalo Diaz Meneses and Pedro J Perez. 2002. The Configuration of The University Image And Its Relationship With The Satisfaction Of Students. Journal of Educational Admninistration, Vol. 40 No. 5, pp. 486505. () MCB UP Limited, 0957-8234 DOI 10.1108/09578230210440311)

Buchari Alma dan Ratih Hurriyati. 2008. Manajemen Corporate dan Strategi Pemasaran Jasa Pendidikan. Bandung: Alfabeta

Drost, J. 1990. Untuk Apa Perguruan Tinggi Didirikan, Dalam Prisma No. 1 Tahun 1990. Jakarta: LP3ES

E A Kuncoro. 2000. Leadership Sebagai Primary Forces Dalam Competitive Strength, Competitive Area, Competitive Result Guna Meningkatkan Daya Saing Perguruan Tinggi, Dalam Buku Manajemen Corporate \& Strategi Pemasaran Jasa Pendidikan. Bandung: Alfabeta 
International Journal Management Science \& Business

Vol 1, No 1, 2019, pp 27-40

Eko Edhi Caroko, Diah Amelia, dan Tedy

Gumilar. 2011. Kiat Kampus Memburu

Devisa.

http://www.majalahtrust.com/bisnis/str ategi/1532.phpm [Diakses Tanggal

01/01/2011, Jam 15:04 WIB]

Fandy Tjiptono. 2005. Strategi Pemasaran. Yogyakarta: PT. ANDI Offset.

Fandy Tjiptono \& Gregorius Chandra. 2005. Service, Quality, and Satisfaction. Yogyakarta: Andi

Fandy Tjiptono. 2008. Strategi Pemasaran. Yogyakarta: PT. ANDI Offset.

Fandy Tjiptono, Gregorius Chandra dan Dadi Adriana. 2008. Pemasaran Strategik. Yogyakarta: Andi

Fandy Tjiptono. 2008. Service Management Mewujudkan Layanan Prima. Yogyakarta: PT. ANDI Offset.

Helena Alves and Ma'rio Raposo. 2010. The Influence Of University Image On Student Behaviour. International Journal of Educational Management Vol. 24 No. 1, 2010 pp. 73-85 (C) Emerald Group Publishing Limited 0951-354X DOI 10.1108/09513541011013060

Husein Umar. 2003. Metode Penelitian Bisnis Untuk Skripsi dan Tesis Bisnis. Jakarta: PT. Gramedia Pustaka Utama.

Inkeles dan Smith. 1974. Becoming Modern: Individual In Six Developing Countries. Massachusetts: Harvard University Press
ITB. International Relation Office (IRO) ITB. http:// www.international.itb.ac.id/web/?p=317 8. [Diakses Tanggal 06/01/2011, Jam 11:15 WIB]

Koran Media Indonesia. 11 Sep 2007. Kampus Di Bandung Menjadi Incaran Mahasiswa Asing. [Diakses Tanggal 08/07/2011, Jam 13.03 WIB]

Koran Tempo. 17 April 2010. Menuju Universitas Berkelas Dunia. [Diakses Tanggal 08/07/2011, Jam 13.03 WIB]

Mohammad S Owlia and Elaine M Aspinwall. 1996. A Framework For The Dimension of Quality In Higher Education. Quality Assurance In Education Volume 4. Number 2. 1996. pp. 12-20 (C) MCB University Press. ISSN 0968-4883

Nha Nguyen and Gaston LeBlanc. 2001. Image and Reputation of Higher Education Institutions In Students' Retention Decision. The International Journal of Educational Management 15/6[2001] 303-311 C MCB University Press, [ISSN 0951-354X]

Parasuraman, A., Zeithaml, V.A. and Berry, L.L. 1985. A conceptual model of service quality and its implications for future research, Journal of Marketing, Vol. 49, Fall, pp. 41-50.

Philip Kotler and Kevin Lane Keller. 2009. Marketing Management 13th Edition. New Jersey-America. Pearson International Edition. 
International Journal Management Science \& Business

Vol 1, No 1, 2019, pp 27-40

QS Quacquarelli Symonds. 2011.

www.topuniversities.com. [Diakses

Tanggal 15/04/2011, Jam 13:59 WIB]

Sugiyono. 2003. Metode Penelitian Bisnis, Bandung: Alfabeta

Sugiyono. 2004. Metode Penelitian Bisnis. Bandung: Alfabeta.

Sugiyono. 2005. Metode Penelitian Bisnis. Bandung: Alfabeta.

Sugiyono. 2007. Metode Penelitian Bisnis. Bandung: Alfabeta.

Suharsimi Arikunto. 2002. Prosedur Penelitian Suatu Pendekatan Praktek, Jakarta: Rineka Cipta

Suharsimi Arikunto. 2006. Prosedur Penelitian Suatu Pendekatan Praktek, Jakarta: Rineka Cipta

Sumarto. 2002. Faktor-Faktor Lingkungan Strategik Dalam Pengembangan Perguruan Tinggi Swasta-Studi Tentang Faktor-Faktor Lingkungan Perguruan Tinggi Swasta Yang Terakreditasi Di Jawa Barat. Disertasi Doktor pada PPS UPI Bandung, Tidak Diterbitkan.

Sutisna. 2001. Perilaku Konsumen \& Komunikasi Pemasaran. Bandung: Rosda Karya

Unpad. Padma Unpad. http://www.padmaedu.com/. [Diakses Tanggal 06/01/2011, Jam 11:00 WIB]

UPI. Office International Education and Relations (OIER) UPI. http://upi.edu/en/index.php?

$C=$ Inter\&S=Office. [Diakses Tanggal 06/01/2011, Jam 11:07]

Webometrics. 2011. Top 12000.

http://www.webometrics.info/top12000 .asp. [Diakses Tanggal 15/04/2011, Jam 13:59 WIB]

Webometrics. 2011. Rank_By_Country. http://www.webometrics.info/rank_by_ country.asp?country=id. [Diakses Tanggal 12/05/11, Jam 10:55] 